Arumna Aryani and Moses Glorino Rumambo Pandin

Faculty of Humanities, Airlangga University

Airlangga University - Campus B, Jalan Dharmawangsa Dalam, Airlangga, Kec. Gubeng,

Surabaya, East Java 60286

arumna.aryani-2020@fib.unair.ac.id; moses.glorino@ fib.unair.ac.id

\title{
BOOK REVIEW "SUBJEKTIVITAS DALAM FILSAFAT POLITIK ALAIN BADIOU DAN SLAVOJ ZIZEK" (SUBJECTIVITY IN POLITICAL PHILOSOPHY BY ALAIN BADIOU AND SLAVOJ ZIZEK)
}

Author: R. Setiawan; Publisher: IRCiSoD; Book thickness: 194 pages; Moulds: First Printing, January 2021; ISBN: 978-623-6699-22-5

\section{Introduction: Background}

The author of this book, R. Setiawan, considers this book as an introduction to voicing reform in the field of politics, especially in Europe. The author is interested in the thoughts of two of the most controversial and topical philosophers about his thoughts on the direction of improvement on the subject of politics and what consequences the communist collapse of the 20th century had on leftist politics in the early 21 st century as well as the spirit and commitment of both against global capitalists and the projecting of the subject in oppositional situations. The author aims to answer the question "should philosophy disturb the world?" in keeping with Badiou's concerns about a philosophy that is no longer based on truth. In addition, the writing of the book is an attempt to trace political subjects according to Badiou's theoretical philosophy of mathematics and ontology as well as Zizek's Lacanian theoretical framework.

Through his relevant writings in looking at political, social, and cultural phenomena, R. Setiawan, described the concept of Badiou and Zizek's subjectivity in detail. The book contains the theoretical frameworks of two controversial philosophers aimed at the author to attract the attention of students, academics, and general readers. The content of this book that offers the idea of the political philosophy of Alain Badiou and Slavoj Zizek is suitable for those who want to think critically even radically.

Alain Badiou and Slavoj Zizek are two philosophers known to be quite provocative in voicing renewal in the face of world politics that is considered dead today. Both simultaneously want to restore the position of a political subject that is considered dead in the intersection of philosophy and politics. The book entitled "Subjectivity in Political Philosophy of Alain 
Badiou and Slavoj Zizek" simply discusses Badiou and Zizek's understanding of political subjects that are considered to have been misguided in capitalism. This book by R. Setiawan consists of three theoretically written chapters. The first chapter, it contains Alain Badiou's background and the theoretical framework of Badiouian. The second chapter deals with the background of Slavoj Zizek and the theoretical framework of Zizekian. Finally, the third chapter, discusses the future of Badiousian and Zizekian subjects regarding the reincarnation of political subjects, St. Paul's militants and radicalizes, as well as Levinasian and Derridean ethical confrontations. The book also raises awareness of how humans should behave wisely in today's dead world of politics.

The book, which contains the spirit of Badiou and Zizek's ideas as an attempt to oppose capitalism that is considered misleading to the political world, is one of the recommended books to review. The philosophy of politics and the practice of democracy today face many challenges that unknowingly deprive identity of the political subject. Therefore, academics, students, political activists, and the general public need to read this book. This book review in addition to fulfilling the task of philosophy of science courses is also expected to open the reader's mind to all possibilities that occur.

\section{Book Summary}

The book entitled "Subjectivity in The Political Philosophy of Alain Badiou and Slavoj Zizek" consists of three chapters as its main subject matter. The first chapter is about the background of Badiou's life and the theoretical framework of Badiouian. The Badiouian theoretical framework includes ontological matters as mathematical philosophy; subject, events, and truth; the future of politics; and the Badiouian subject proposition. The second chapter of the book discusses at a glance Zizek and his ideas. Zizek's theoretical framework consists of Lacanian psychoanalysis, ideology: naivety and cynicism, ideological plague: desire and fantasy, subjectivity as radical action, and Zizek's subject proposition. The last chapter, the third chapter, contains the future of Badiouian and Zizekian subjects divided into several sub-chapters: the reincarnation of political subjects, St. Paul the militant and radical, and the ethical confrontation of Levinasian and Derridean. The content presented by the author in each chapter can provide answers for readers who have concerns about the position of political subjects that are considered incompatible with their position. 
In the first chapter, it is explained that Alain Badiou, son of Raymond Badiou was a philosopher synonymous with mathematics, love, ontology, and communism. Badiou views ontology to the extreme as a mathematical logical consequence and not a core organ of philosophy. He explained the ontological problem using set theory and the main problem is that the ontologist only explains of the One because the One can explain an Existence. Badiou defines a subject into six points: the subject is not substance, the subject is not a hollow Lacanian subject, the subject is not an encyclopedic accumulation of logical knowledge, the subject is not a homogeneous presentation, the subject is not an inevitability, and the subject is neither projection nor origin. Badiou implies that the subject is a sweetie station of truth. According to Badiou, philosophy needs to be revised. The interpretation, philosophy is a long struggle of sanctions that are present and react to the beliefs of the former. It applies logic to thinking based on authentic situations. It takes an event (possible impossibility) for a political moment to be present and the birth of a militant subject. (Pages 17-19)

The second chapter describes a Slavoj Zizek born on 21 March 1949 in Ljubljana, Slovenia (formerly part of Yugoslavia). Around the 1960s, Zizek studied western philosophy in Zagreb. The essence of Zizek's thinking is how he criticizes theories about the subjects and tricks that work today, as well as melting them in today's social conditions. Zizek's idea of thought ends in the trinity of the Hegel-Marx-Lacan concept. Hegel deals with discourses on dialetic (substance) and social subjects. Marx deals with discourses on ideology. While Lacan's problem is used as a formulation of the concept of the subject psychologically. Of these three philosophers, Zizek's radical subjects were accommodated and criticism of ideology could be simulated. (Pages 57-60)

Zizek's subjects are Hegelian, Marxist, and Lacanian. Zizek strives to evoke subjects that have always been negated and ignored. Zizek's idea emphasizes how he formulates the concept of the subject to escape the snare of capitalism. Beginning with an understanding of the subject in Lacanian psychosis symptoms, Zizek attempts to revive the subject. Lacan's psychoanalysis became the basis of Zizek's thinking which then directed the subject's problems to his social sphere. In the concept of Zizekian, ideology is understood as false consciousness. That is, what seems incompatible with reality. There is something manipulative of the subject however, they are unconscious. The ideological fantasies that exist in us should not make us do anything contrary to our principles. However, sometimes subjects manifest and materialize unconsciously due to desire and fantasy. For Zizek, a radical action is an act that is not realized, understood, and predicted when it comes. Subjectivity here is how the subject can realize 
reality. Subjects with radical acts describe non-desireless actions. In politics, it is common for things that trigger the intolerance of a party, ranging from religion, customs, and others. Zizek's idea opens up the possibility that political subjects never die. The subject is only covered by power rather than destroyed by power. (Pages 61-92)

Today humans live in a disruptive and question-filled society. Many figures take advantage of the advantages behind political problems. Democracy and freedom make capital groups a thorn. The system of freedom was ultimately dominated by the power of capitalism. Until the emergence of antagonism communism was the main opponent of capitalism. Often see the nuances of communism being considered bad. The author argues that communism is bad, it is not its ideology but rather its failed practice. Communism and capitalism both had disabilities in practice. It should be noted, humans must not drop each other's ideology, but for sure, humans must fight for humanity. (Pages 93-125)

Historically, Badiou seems important to Zizek's thinking because it is the reference. Badiou and Zizek project the subject against each other. Zizek's interest in the idea was to develop politics and contribute to anti-capitalism politics. Zizek and Badiou were concerned about the barren resistance of capitalism, the resistance movement instead energized the project of capitalism. Zizek points out that society is anti-capitalism however, there is no action. Badiou provided a crucial solution, realizing that religion had destabilized Marx's materialist politics and confused the study of philosophy. Badiou's ontology study dismantles that problem-One. Regrettably, public believe in the existence of heaven and religion. Thus, do not realize that capitalism is also engaged in religion so that our beliefs are governed by the capital system. Comparisons of Badiou and Zizek's ideas differ in terms of ontology, subjectivity, and procedures of political action but they agree on the threat of a political subject: capitalism. (Pages 126-141)

From both chapters, Badiou and Zizek offer an eye-catching frame of mind about how the political future and the subject matter are. The author is quite detail in writing this book which before the discussion about the future of political subjects has been explained in advance described the idea of Badiou and Zizek that can make it easier for readers to understand the next chapter.

In the last part, the third chapter explains the concept of subjects and actions that are not driven by the motives of power. This brings us to how Badiou interprets the quotation in Paul's Epistle to the Romans. According to Badiou, St. Paul was the subject and he was a 
declarator or mediator of abstraction leading to the declaration. St. Paul became the bridge of truth-event presence through the declaration of the Resurrection of Jesus Christ. Truth-event is not solely from the factual events themselves, but it is the meaning of how faithful the subject is in dealing with problems. His thinking is the same as Zizek's logic of "reality is in plain sight". However, the subject needs encouragement in order to break down the establishment so that no one can lie to the subject. From the above statements, there is a point that Badiou and Lacan emphasize, which is that the moment of presence of the militant subject results from the encouragement of st. Paul's resurrection. (Pages 143-168)

One of the post-structuralist philosophers, Derrida, came up with postulation deconstruction. There is a difference between Derrida and Badiou at a critical point. Derrida was intrigued by Levinas' efforts at the idea of thinking of another and was fascinated by his antiontology. Meanwhile, Badiou sees it as something that can change intellectual and neoliberal structures. Levinas in his efforts explained pure ethics on the other face and impressed morality. With the popularity of Derrida's deconstruction, the Levinasian phenomenon with the ethics of facial alteration is evidenced by heavy radical changes to show its reality. Derrida and Levinas have become a discursive bridge between Badiou and Zizek in the revival of the subject. Badiou would gladly restore Christianity himself and Zizek fully acknowledged Mahis Badiou's writings about St. Paul. Despite both opinions, Badiou's radical ideas are far from reality, including Zizek's, and likely for some time to come. (Pages 169-179)

Badiou and Zizek's ideas are presented to the reader after reading. This book influences the reader to think more critically and deeply about the problems that exist in the world of political philosophy. Humans must be louder in calling for philosophical thinking that Badiou considers out of place.

\section{Advantages and Disadvantages of Books}

The study of political philosophy according to Alan Badiou and Slavoj Zizek written by R. Setiawan became one of the books that reviewer could recommend to read. The book describes Badiou and Zizek's subjectivity patterns in meticulous and detailed detail. The author wrote this book with great relevance as a reference in looking at political and social issues. By reading this book, we can find out the thoughts of two provocative philosophers who think critically. The book is theoretically composed and can be used as a reference if readers want to know more about political philosophy. 
The disadvantage in a book is that it writes a style that cannot be understood in a single reading. Several phrases use mathematical theory such as the example on page 24 of paragraph two. These sentences cannot be immediately understood and understood by ordinary readers. In addition, there is a scientific term mentioned by the author but no description of the definition of the word.

The book presents the ideas of Alain Badiou and Slavoj Zizek who are two left-handed philosophers. The two both examined the political subject of political issues and voiced the renewal of the political face. Badiou's thinking is based on mathematical ontology and Zizek is based on Marxist psychoanalysis. Both argue that the subject in politics has begun to look vaguely together. Therefore, the two made their ideas to fix the political subject in many crises that existed at that time.

Based on the content of the entire book, the author, R. Setiawan describes the subjectivity of Badiou and Zizek which is built on mathematical concepts and psychoanalysis and describes radical ideas about subjects in politics. This paper is very interesting and can be used as a reference for those who want to delve into philosophy and political history. My advice after reviewing this book is that readers are expected to be able to better understand and appreciate the form of political action today.

Arumna Aryani and Moses Glorino Rumambo Pandin Airlangga University

\section{BIBLIOGRAPHY}

1. Setiawan R. Subjektivitas dalam Filsafat Politik Alain Badiou dan Slavoj Zizek. Yogyakarta: IRCiSoD; 2021. 194 p. 


\section{Book Cover Image}

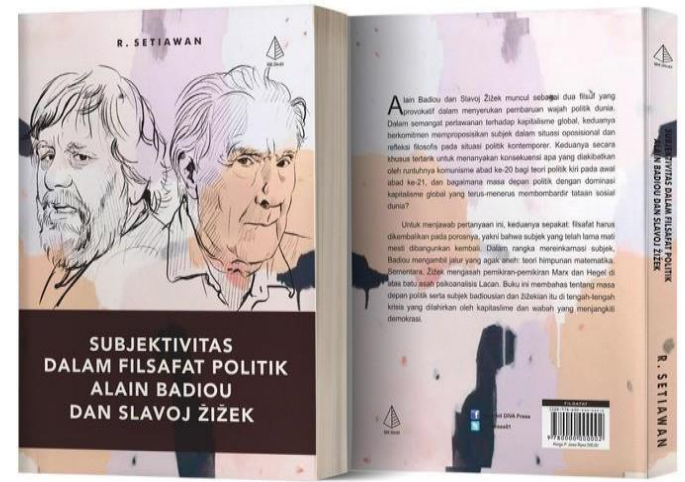

\section{Author Biography}

The author of the book "Subjectivity in Political Philosophy Alain Badiou and Slavoj Zizek" was born in Gresik on December 31, 1989. R. Setiawan graduated from Surabaya State University in 2013 with a bachelor's degree. Then in 2015, he again graduated S2 from Gadjah Mada University study program of Literature. Before publishing the book "Subjectivity in Political Philosophy of Alain Badiou and Slavoj Zizek", R. Setiawan has released several books entitled The Recipe of Literature: The Unlikely Way A Professor Mastering Literature in 2017, Postmodern Literary Criticism in 2018, Postcolonial: Discourse, Theory, and Application in 2018. At the back of the book, the author explains that he will continue to write literary, social, cultural, philosophical, and other criticisms. Until this writing is written, the author still teaches at PGRI Adi Buana University Surabaya. 